\title{
Analisisi Kesalahan Mahasiswa Matematika UNU Blitar Dalam Menyelesaikan Soal Matematika Materi Fungsi Berdasarkan Kriteria Watson
}

\author{
Ardhi Sanwidi ${ }^{1}$ \\ ${ }^{1}$ Program Sstudi Matematika Universitas Nahdlatul Ulama Blitar \\ Email: ${ }^{1}$ ardhisanwidi@gmail.com
}

\begin{tabular}{l}
\hline Tersedia Online di \\
\hline http://www.jurnal.unublitar.ac.id/ \\
index.php/briliant \\
\hline \\
\hline Sejarah Artikel \\
\hline Diterima pada 9 Februari 2018 \\
Disetuji pada 10 Januari 2018 \\
Dipublikasikan pada 13 Februari \\
2018 Hal. 128-132 \\
\hline
\end{tabular}

Kata Kunci:

analisis kesalahan, materi fungsi, kriteria watson

\section{DOI:}

http://dx.doi.org/10.28926/briliant .v3i1.138

\begin{abstract}
Abstrak: Penelitian ini bertujuan untuk mendeskripsikan kesalahan apa saja yang dilakukan mahasiswa matematika UNU Blitar dalam menyelesaikan masalah matematika pada materi fungsi berdasarkan kriteria Watson. Kriteria kesalahan yang dilakukan mahasiswa adalah kesalahan data hilang dan kesalahan manipulasi tidak langsung. Mahasiswa mendapatkan jawaban tanpa didasari alasan atau menggunakan cara yang tidak logis menyelesaikan masalah. Selain itu mahasiswa juga kurang teliti dan kurang memahami soal sehingga subjek tidak mendapatkan data atau informasi yang terdapat dalam soal.
\end{abstract}

Mahasiswa program studi matematika secara umum, dalam pembelajarannya mempunyai tujuan yang ingin dicapai yaitu diharapkan mahasiswa terampil pada aspek kognitif, afektif dan psikomotorik, dimana tujuan pembelajaran perlu diarahkan pada upaya menumbuh kembangkan penalaran mahasiswa. Hal ini sesuai dengan tujuan pembelajaran matematika dalam kurikulum (2013), yakni (1) Melatih cara berfikir dan bernalar dalam menarik kesimpulan, misalnya melalui kegiatan penyelidikan, ekslorasi,eksperimen, menunjukkan kesamaan, perbedaan, konsistensi dan inkonsistensi, (2) Mengembangkan aktifitas kreatif yang melibatkan imajinasi, intuisi, dan penemuan dengan mengembangkan divergen, orisinil, rasa ingin tahu, membuat prediksi dan dugaan serta mencoba-coba, (3) Mengembangkan kemampuan memecahkan masalah (4) Mengembangkan kemampuan menyampaikan informasi, mengkomunikasikan gagasan antara lain melalui pembicaraan lisan, catatan, grafik, diagram, dalam menjelaskan gagasan.

Dari matematika yang telah diajarkan sangatlah penting juga untuk mengevaluasi apa saja yang sudah dapat dicapai dan apa yang masih menjadi kendala dalam mempelajari atau menyelesaikan masalah dalam matakuliah matematika. Hasil evaluasi mahasiswa merupakan salah satu cara untuk dapat mengetahui sejauh mana perkembangan mahasiswa dan tercapainya tujuan belajar. Salah satu alat atau pendukung untuk mengevaluasi hasil belajar mahasiswa adalah ujian, yang didalam ujian tersebut terdapat beberapa soal yang 
bisa mengukur tingkat pemahaman mahasiswa dan kesalahan - kesalahan yang dialami mahasiswa pada materi tertentu.

Dari hasil observasi yang dilakukan, pembelajaran pada mata kuliah Matematika Dasar di program studi matematika UNU Blitar yang disampaikan dosen telah menggunakan pendekatan konstruktivis yang berpusat pada mahasiswa dan terlihat berjalan sangat baik. Akan tetapi dalam hal hasil evaluasi ketika mahasiswa dihadapkan pada soal fungsi tentang jenis - jenisnya mereka masih kebingungan menyelesaikan soal tersebut dan salah dalam menjawab soal tersebut. John Watson (2006) mengklasifikasi kesalahan dalam mengerjakan soal, yaitu: (i) data tidak tepat innappropriate data) disingkat id, (ii) prosedur tidak tepat (inappropriate procedure) disingkat ip, (iii) data hilang (ommited data) disingkat od, (iv) kesimpulan hilang (omitted conclusion) disingkat oc, (v) konflik level respon (response level conflict) disingkat rlc, (vi) manipulasi tidak langsung (undirected manipulation) disingkat um, (vii) masalah hirarki keterampilan (skills hierarchy problem) disingkat shp, dan (viii) selain ke-7 kategori di atas (above other) disingkat ao.

Berdasarkan hasil temuan tersebut, peneliti tertarik untuk menggali lebih dalam lagi mengenai alasan atau kesalahan yang dialami mahasiswa dalam menyelesaikan soal pada mata kuliah Matematika Dasar dengan topik bahasan Fungsi mahasiswa matematika UNU Blitar berdasarkan kriteria Watson. Konsep yang dimaksud adalah Fungsi, yaitu pada materi pengenalan Fungsi yang diajarkan. Temuan yang didapat dilapangan, mahasiswa masih bingung membedakan macam dan jenis fungsi pada matematika. Selain itu pemilihan materi fungsi juga karena fungsi merupakan dasar untuk dari salah satu materi matematika yang akan dipakai sampai semester berikutnya dan sebenarnya merupakan materi matematika yang telah didapat di jenjang pendidikan SMA. Sehingga seharusnya dalam tingkat perdosenan tinggi, mahasiswa sudah menguasai materi tersebut

\section{METODE}

Jenis penelitian ini adalah penelitian kualitatif. Subjek penelitian ini adalah mahasiswa semester I angkatan 2016/2017 UNU Blitar sebanyak 36 Mahasiswa yang terdiri dari 8 mahasiswa berkemampuan tinggi, 17 mahasiswa berkemampuan sedang dan 11 mahasiswa berkemampuan rendah. Pengelompokan ketiga kategori tersebut berdasarkan pada skala penilaian yang ditetapkan oleh Arifin (2009), yaitu: (1) kemampuan matematika tinggi jika $80 \leq$ nilai $\leq 100$, (2) kemampuan matematika sedang jika $60 \leq$ nilai $<80$, (3) kemampuan matematika rendah jika $0<$ nilai $<60$. Pemilihan subjek berdasarkan beberapa pertimbangan, yaitu: (1) mahasiswa yang paling banyak melakukan kesalahan, (2) kesediaan mahasiswa menjadi subjek, dan (3) kemampuan mahasiswa dalam berkomunikasi dan mengungkapkan pendapat.

Instrumen utama pada penelitian ini adalah peneliti sendiri. Teknik pengumpulan data pada penelitian ini adalah tes dan wawancara. Data yang diperoleh dengan tes adalah kesalahan yang dilakukan mahasiswa. Data yang diperoleh dengan wawancara adalah jenis dan letak kesalahan yang dilakukan mahasiswa serta penyebab terjadinya. Teknik pemeriksaan keabsahan data yang digunakan adalah triangulasi metode. Triangulasi metode dilakukan dengan membandingkan data hasil tes dan data hasil wawancara. Analisis data yang 
diguna-kan mengacu pada analisis data menurut Huberman,dkk (2014) yakni reduksi data, penyajian data, dan penarikan kesimpulan.

\section{HASIL}

Peneliti memberikan tes kepada 36 mahasiswa mengenai materi fungsi sebanyak 3 butir soal, yaitu: (1) tentukan daerah asal dan range fugsi $\mathrm{f}(\mathrm{x})=$ $x^{2}+3$ bila $x \in B$ dan $B=\{x \mid-3<x \leq 2\}$, (2) diketahui $\mathrm{f}(\mathrm{x})=\mathrm{ax}+\mathrm{b}$ dengan $\mathrm{f}(-4)=-3$ dan $\mathrm{f}(2)=9$. Tentukan nilai a dan $\mathrm{b}$ kemudian tulis fungsinya, (3) diberikan suatu rumus fungsi $\mathrm{f}(\mathrm{x})=\mathrm{ax}+\mathrm{b}$, jika $\mathrm{f}(1)=12$ dan $\mathrm{f}(-1)=8$ tentukan nilai dari $a^{2}+b^{2}$. Hasil tes menunjukkan 22 mahasiswa menunjukkan jawaban benar dan 14 mahasiswa melakukan kesalahan yang terdiri dari 2 mahasiswa berkemampuan tinggi, 6 mahasiswa berkemampuan sedang dan 6 mahasiswa berkemampuan rendah. Dari tiga kriteria tersebut dan beberapa pertimbangan dari peneliti, dipilih mahasiswa berkemampuan rendah yang mengalami tingkat kesalahan yang paling banyak.

Hasil analisis data pada kesalahan data tidak tepat (inappropriate data/id) menunjukkan prosentase sebesar 16,71\%. Hal ini menunjukkan bahwa kategori kesalahan yang sangat rendah. Kategori prosentase ini sesuai dengan pengklasifikasian bahwa $\mathrm{P}<20 \%$ termasuk tingkat yang sangat rendah (Arikunto, 2006). Kesalahan ini terdapat pada soal nomor 1 dan 3. Mahasiswa lupa menulis rumus dalam menyelesaikan permasalahan tersebut, dan salah dalam memasukkan data dalam menyelesaikan masalah tersebut. Hasil analisis data pada prosedur tidak tepat (inappropriate procedure/ip) menunjukkan prosentase $28,34 \%$. Hal ini menunjukkan bahwa kategori kesalahan rendah. Mahasiswa melakukan kesalahan prosedur tidak tepat adalah kurang memahami cara mencari data dan tidak mengurutkan data. Hasil analisis data pada kesalahan data hilang (ommited data/od) menunjukkan prosentase kesalahan yang cukup tinggi yaitu 52,45\%. Kesalahan data hilang terletak pada semua butir soal. Mahasiswa melakukan kesalahan kurang lengkap dalam memasukkan data dan kurang teliti ketika mendata dan memahami soal

Hasil analisis data pada kesalahan kesimpulan hilang (omitted conclusion/oc) menunjukkan kesalahan yang rendah dengan prosentase 29,37\%. Pada tingkat kesalahan ini mahasiswa lupa belum menuliskan kesimpulan yang telah diperoleh dalam menyelesaikan masalah pada soal dan kurang teliti dalam membaca apa yang dimaksud dalam soal. Hal ini terjadi pada semua butir 1 dan 3 . Hasil analisis data pada kesalahan konflik respon (response level conflict/rlc) menunjukkan prosentase $18,20 \%$. Hal ini menunjukkan bahwa kategori ini sangat rendah dan terjadi pada semua butir soal. Mahasiswa pada tingkat kesalahan ini menunjukkan kurang kesiapan dalam menyelesaikan soal serta kurang memahami maksud dari soal. Hasil analisis data pada kesalahan manipulasi tidak langsung (undirected manipulation/um) menunjukkan prosentase 57,6\%. Hal ini bisa masih dalam level tinggi. Mahasiswa kurang teliti dalam menggunakan alasan untuk menyelesaikan soal dan kurang teliti dalam pengerjaannya. Kesalahan pada tingkat ini terjadi pada semua butir soal.

Hasil analisis data pada kesalahan masalah hirarki keterampilan (skills hierarchy problem/shp) diperoleh prosentase sebesar 15,57\%. Hal ini menunjukkan level yang sangat rendah untuk tingkat kesalahan ini. Mahasiswa kurang teliti dalam melakukan perhitungan dan salah dalam menuangkan hasil 
kedalam suatu rumus fungsi. Hal ini terjadi pada butir soal nomor 2. Hasil analisis data pada kesalahan selain kategori ketujuh kategori diatas (above other/ao) menunjukkan prosentase sebesar $17,12 \%$. Penyebab siswa melakukan kesalahan ini adalah mahasiswa sedikit bingung dalam mencari hasil untuk mencari nilai a dan $b$ pada butir soal nomor 3 dan hanya mengisi sebisanya dari pada tidak diisi atau dijawab.

\section{PEMBAHASAN}

Berdasarkan pemaparan pada hasil penelitian, diperoleh bahwa kesalahan pada tingkat level yang paling tinggi menurut kriteria Watson yang dilakukan oleh subjek tingkat kemapuan rendah dalam menyelesaikan soal pada materi fungsi adalah kesalahan data hilang dan kesalahan manipulasi tidak langsung.

Kesalahan data hilang dilakukan oleh subjek, hal ini ditandai dengan subjek yang kurang teliti dan kurang memahami soal sehingga subjek tidak mendapatkan data atau informasi yang terdapat dalam soal yang mengakibatkan penyelesaian soal tidak lengkap. Hasil ini sejalan dengan pernyataan dari Aqillah (2012) tetapi dengan materi yang berbeda namun sejalan dengan Aqillah (2012) bahwa peserta didik melakukan kesalahan dalam pemahaman soal dalam menyelesaikan masalah pada soal trigonometri.

Kesalahan manipulasi tidak langsung dilakukan oleh subjek. Kesalahan manipulasi tidak langsung ini berupa mendapatkan jawaban tanpa didasari alasan atau menggunakan cara yang tidak logis yang digunakan subjek untuk yang disebabkan karena subjek terburu-buru dalam mengerjakan soal dengan kata lain subjek tidak teliti. Hasil ini sejalan dengan Sari (2012) bahwa kesalahan yang dilakukan siswa dalam mengerjakan soal aljabar yaitu kesalahan karena mendapatkan jawaban tanpa didasari alasan.

Dari penjelasan hasil penelitian di atas secara umum kesalahan yang dilakukan mahasiswa adalah kesalahan data hilang dan kesalahan manipulasi tidak langsung. Hal ini disebabkan karena mahasiswa kurang lengkap dalam memasukkan data dan kurang teliti ketika mendata dan menyelesaikan soal. Dari hasil tersebut maka mahasiswa perlu melakukan banyak latihan soal dengan variasi soal yang berbeda-beda untuk meningkatkan pemahaman dalam menyelesaikan masalah yang terkait dengan pengolahan data serta untuk melatih ketelitian dalam mendata dan menghitung.

\section{KESIMPULAN}

Berdasarkan pembahsan dan dari data yang diperoleh dalam penelitian, maka dapat diambil kesimpulan bahwa mahasiswa melakukan kesalahan dalam menyelesaikan masalah matematika pada materi fungsi menurut kriteria Watson adalah kesalahan data hilang dan kesalahan manipulasi tidak langsung. Hal ini disebabkan karena mahasiswa mendapatkan jawaban tanpa didasari alasan atau menggunakan cara yang tidak logis untuk menyelesaikan masalah yang disebabkan karena subjek terburu-buru dalam mengerjakan soal dengan kata lain subjek tidak teliti. Selain itu mahasiswa juga kurang teliti dan kurang memahami soal sehingga subjek tidak mendapatkan data atau informasi yang terdapat dalam soal yang mengakibatkan penyelesaian soal tidak lengkap.

131 BRILIANT: Jurnal Riset dan Konseptual Volume 3 Nomor 1, Februari 2018 


\section{SARAN}

Sebaiknya mahasiswa diberikan banyak soal yang bervariasi dan banyak mengerjakan latihan soal tentang materi fungsi dan perlu penekanan konsep yang mendasar tentang materi fungsi untuk mengurangi kesalahan - kesalahan yang dialami oleh mahasiswa.

\section{DAFTAR RUJUKAN}

Arifin, Z. (2009). Evaluasi Pembelajaran. Bandung: PT Remaja Rosdakarya Arikunto, Suharsimi. 2001. Dasar-dasar Evaluasi Pendidikan. Jakarta: Bumi Aksara

Aqilah. 2012. Analisis Kesalahan Peserta Didik dalam Menyelesaikan Soal Pembuktian Identitas Trigonometri Kelas X.1 SMA Islam Sultan Agung 1 Semarang. (Online). (http://library.walisongo.ac.id/digilib/files/disk1/ 141/ jtptiain--aqiilah083-7004-1-skripsih.pdf), diakses 10 Nopember 2017.

Huberman, dkk. 2014. Qualitative Data Analysis. Third Edition Copyright (C) 2014 SAGE Publications, Inc

Sari, L.A. (2013). Diagnosis Kesalahan Siswa Sekolah Menengah Pertama dalam Menyelesaikan Masalah Faktorisasi Bentuk Aljabar. Prosiding Seminar Nasional Matematika dan Pendidikan Matematika FMIPA UNY, 9 November 2013. (Online). http://eprints.uny.ac.id/10774/1/P\%20\%2051.pdf), diakses 11 Nopember 2017.

Watson, J. 2006. Pro Oracle Collaboration Suite. Springer - Verlag 